\title{
Veiledning for nyansatte i barnevernet
}

\author{
Av Camilla Lauritzen og Benedikte Aas, \\ Regionalt kunnskapssenter for barn og unge (RKBU), Nord \\ Det helsevitenskapelige fakultet \\ UiT- Norges Arktiske Universitet
}

Adresse for kommunikasjon:

Camilla Lauritzen, RKBU Nord, Universitetet i Tromsø, Gimleveien 78, 9037 Tromsø

Tlf: 77645871

Mobil: 92890601

E-post: camilla.lauritzen@uit.no 
Veiledning for nyansatte i barnevernet. (Artikkelens tittel)

\section{Sammendrag (avsnittstittel)}

Myndighetene ønsker å innføre veiledet førsteår for nyansatte i barnevernet, med hensikt om å redusere frafall, samt å bidra til profesjonell utvikling av nyansatte. Dette prosjektet hadde som formål å undersøke hvor langt man har kommet med å innføre veiledning for nyansatte og øvrige ansatte i det kommunale barnevernet. Deltakerne i studien besto av ansatte i det kommunale barnevernet $(N=228)$, hvor $71.7 \%$ av respondentene hadde lederansvar. De ble invitert til å fylle ut et elektronisk spørreskjema. Resultatene av studien viste at det til en viss grad var etablert veiledning i den kommunale barneverntjenesten, men veiledningen som tilbys er av varierende karakter. Det kan imidlertid stilles spørsmåltegn ved kvaliteten på den faglige veiledningen som ble gitt i tjenestene, da det var stor variasjon i veiledernes formelle kompetanse. Videre fant vi at ikke alle nyansatte hadde tilgang til systematisk faglig veiledning på det tidspunktet vi gjennomførte undersøkelsen. Dette hang sammen med ressurstilfang og tilgjengelig kompetanse. Et annet funn i denne studien var at om lag en fjerdedel av de ansatte i den kommunale barneverntjenesten ofte vurderte å slutte i jobben sin, og at det veiledningstilbudet som finnes i tjenestene i dag ikke synes å ha noen effekt på ansattes ønske om å slutte. Dette er funn som bør undersøkes nærmere. 


\section{English abstract (avsnittstittel)}

There are extensive requirements to employees in child welfare services, and workers within these services have to deal with many professional, ethical and juridical challenges. The child welfare services have difficulties when it comes to recruiting and retaining qualified personnel in countries across the world. The child welfare services have high attrition rates, which also may have consequences for the quality of the services offered. Several disadvantages associated with being a child welfare worker have been studied extensively. Supervision has been suggested as a solution to reduce high turnover rates and to contribute to the professional development of new employees. Norwegian authorities have initiated implementation of supervision for new employees in the child welfare services, and the aims are to reduce dropout and to contribute to the professional development of new employees.

This project aimed to examine the status quo in terms of supervision within the child welfare services. The participants consisted of employees in the municipal child welfare ( $\mathrm{N}=228)$, where $71.7 \%$ of respondents had managerial responsibility. They were invited to fill out an online questionnaire. Results of the study showed that supervision was established only to a certain extent, and the content of the supervision was of varying character. There was considerable variation in the supervisors' formal qualifications. Furthermore, several new employees did not have access to systematic professional supervision at the time we conducted the survey. This was related to a lack of resources and available expertise. Another important finding in this study was that about a quarter of the employees in the municipal child welfare service often considered quitting their 
jobs, and that supervision provided within the services today did not seem to have any effect on employees' intention to quit. These findings should be investigated further. Key words: Supervision, Child protection, professional development, intention to quit 


\section{Bakgrunn og kunnskapsgrunnlag (avsnittstittel)}

Det blir stilt omfattende krav til ansatte i barneverntjenesten, og arbeid med barnevernssaker byr på faglige, etiske og juridiske utfordringer (Killén, 1998). I mange land snakkes det om en krise i barneverntjenestene, fordi barnevernet sliter med både å rekruttere og holde på kvalifisert personell (Westbrook, 2006). Barnevernet som tjeneste har en utfordring med høyt frafall av ansatte, som også får konsekvenser for kvaliteten på barneverntjenestene (Westbrook, 2006). Ulempene knyttet til det å være barnevernarbeider har blitt studert inngående. Ellett og kolleger har pekt på følgende utfordringer; utilstrekkelig kompensasjon, mange saker, lang arbeidstid og vaktansvar, mye papirarbeid, hyppige endringer i retningslinjer og regelverk, personlig sikkerhet, utilstrekkelig opplæring og veiledning, ufrivillige klienter med komplekse problemer, ikke nok ressurser til å hjelpe klienter, dårlige forfremmelsesmuligheter i jobben, medias sensasjonsdekking av saker og negativ holdning til barnevernet i befolkningen (Ellett, 2003). Det er dokumentert at slike negative påkjenninger i yrkeshverdagen i sosialt arbeid kan lede til utbrenthet (Ede, 2011). Videre har mange studier sett på forholdet mellom høyt frafall av ansatte og fornøydhet i jobben. Her har man sett at ansatte i barnevernet i stor grad oppgir at de vurderer å slutte i jobben, og at de oppgir at jobben innbefatter mye stress (Westbrook, 2006). Likevel fant man at de samme ansatte oppga at de var fornøyd med jobben sin. Westbrook konkluderer med at fornøydhet med jobben ikke har betydning for om ansatte vil slutte på grunn av utslitthet eller frustrasjon. De tre faktorene som var høyest korrelert med ønske om å slutte i jobben var; stor mengde papirarbeid, lite lønnsmessig uttelling og manglende støtte i yrkeshverdagen (Westbrook, 2006). I følge en rapport fra 2014 om turnover i det kommunale barnevernet, var den 
gjennomsnittlige gjennomtrekksraten av personell 31,5 \% fra 2010 til 2011 (Johansen, 2014). Sammenlignet med andre arbeidsplasser som sosialkontor, grunnskole, barnehage, institusjoner innen barne- og ungdomsvern, industri og varehandel, var det kun institusjoner innen barne- og ungdomsvern som hadde en høyere gjennomtrekksrate av personell (Johansen, 2014).

Høyt frafall og store belastninger, spesielt for nyansatte, er dermed en kjent utfordring for barneverntjenesten, og regjeringen har som en følge av dette iverksatt ei satsning, barnevernløftet, for å styrke tjenestene (Barne- likestillings og inkluderingsdepartementet, 2012-2013). Barnevernløftet er regjeringens satsning på utvikling av den kommunale barneverntjenesten og innebar blant annet et ressursløft i form av nye tjenester og ny organisering. Kompetanseheving står sentralt i barnevernløftet. Et viktig aspekt i arbeidet med å heve kompetansen i barnevernet er veiledning og ideen er å innføre veiledet førsteår for nye ansatte i barnevernet. Veiledet førsteår var regjeringens plan for å imøtekomme nyutdannede og nytilsatte i barnevernet, som har gitt uttrykk for en krevende overgang fra utdanning til yrkespraksis.

Satsningen på veiledet førsteår for alle nyansatte i barneverntjenestene i Norge kan spores helt tilbake til Befringutvalgets utredning om Barnevernet (NOU 2009:8). Utvalget konkluderte med at treårig bachelorutdannelse ikke var tilstrekkelig for å inneha stillinger i Barnevernet, og foreslo å innføre minimum ett års veiledning av godkjente fagfolk for alle nyutdannede barnevernsansatte. For å imøtekomme dette forslaget har Bufdir initiert oppretting av videreutdanning i Barnevernfaglig veiledning ved 6 studiesteder rundt om i Norge. For å kunne ta denne videreutdanningen, forutsettes det minimum 3 års erfaring i barneverntjenesten og ansettelse i kommunalt barnevern under 
videreutdanningen med mulighet for å drive veiledning som arbeidsoppgave. Tanken er at ved å utdanne erfarne ansatte i tjenestene rundt om i Norge, så skal ei ordning komme på plass der nyansatte får tilbud om tett oppfølging gjennom veiledning i løpet av sitt første år. Denne veiledningen skal være noe mer enn støtte i vanskelige saker eller veiledning i saksbehandling. Veiledningen man ønsker skal innføres for å styrke tjenestene har som målsetting å være faglig veiledning som leder til profesjonell utvikling (Barne- likestillings og inkluderingsdepartementet, 2011-2012).

\section{Veiledningsteoretiske perspektiver (avsnittstittel)}

For å imøtekomme de store belastningene knyttet til å arbeide i barnevernet, samt for å redusere frafall i barneverntjenestene, har mange fagfolk tatt til orde for å innføre systematisk veiledning av nyansatte. For å være en god yrkesutøver, bør man ha noen grunnleggende ferdigheter. Evnen til refleksjon over egen profesjonsutøvelse, samt evnen til å innøve og utvikle god barnevernfaglig praksis er sannsynligvis ikke til stede hos nyutdannede, og deres profesjonelle kompetanse utvikles dermed best gjennom veiledning (Smith, 2010). Når det er sagt er det nødvendig å se nærmere på veiledning som begrep. Begrepet veiledning brukes i mange og ulike sammenhenger, og det finnes ikke en definisjon som alle fagmiljø er enige om (Tveiten, 2013). Det er dermed slik at ulike aktører legger ulikt innhold til begrepet, avhengig av ståsted og profesjon. Veiledningsfeltet er et uoversiktlig teoriområde, som omfatter et utall metoder, modeller og teorier om veiledning (Skagen, 2011). Videre er norsk veiledningstradisjon svært variert, og samtaleveiledningen står i en sterk posisjon (Skagen, 2011). 
Innenfor barnevernfaglig arbeid er det gjerne tre ulike betydninger som tillegges veiledning; saksveiledning, debrief og faglig veiledning for profesjonell utvikling (Killén, 2012). Med saksveiledning menes en helt konkret veiledning i å gjennomføre kjerneoppgavene i barnevernet: eksempelvis hvordan håndterer man bekymringsmeldinger, hvordan går man fram i undersøkelsesarbeid, hvordan dokumenterer og loggfører man arbeid underveis. Veiledning i dette perspektivet ligner dermed det som i veiledningsteorien vises til som håndverkstradisjonen (Tveiten, 2008). Håndverkstradisjonen innen veiledning springer ut av et tradisjonelt mester/lærlingperspektiv, der innfallsvinkelen til å lære et yrke eller en profesjonalitet er gjennom mesterens formidling av kunnskap og ferdigheter. I denne tradisjonen lærer den som veiledes gjennom å se på hva veilederen gjør, og veiledning blir således begrenset til konkrete ferdigheter, ikke til profesjonell utvikling hos den enkelte (Lauvås og Handal, 2000; Tveiten 2008).

Med debrief henvises det til en støtte og veiledning i tilknytning til saker og opplevelser som har opplevdes som særskilt belastende. Debriefing er gjerne en samtale eller flere om spesifikke hendelsesforløp, der hensikten er at den som har hatt saken eller opplevelsen skal få startet prosessen med å bearbeide hendelsen, slik at negative følger kan forebygges (Malt, 2009). I veiledningsteoretisk sammenheng hører denne typen veiledning tradisjonelt hjemme i terapitradisjonen og har sitt utspring i psykologien (Tveiten, 2008). I terapitradisjonen betrakter man veiledning som en personlig prosess, der følelsesaspektet har en sentral plass. Veiledning som springer ut av terapitradisjonen har gjerne et element av aktiv bearbeiding av egne følelser, der yrkesutøveren søker å 
videreutvikle sin emosjonelle intelligens for således å kunne imøtekomme klienters behov på en mer hensiktsmessig måte (Tveiten, 2008).

Den tredje og siste innfallsvinkelen til veiledning som fagområde kalles gjerne faglig veiledning for profesjonell utvikling, og er en type veiledning som i større grad har en pedagogisk målsetting. Med faglig veiledning menes en utviklings- og læreprosess, med målsettingen at den skal bidra til at nyutdannede lærer metodisk arbeid, utvikler fagligetiske prinsipper og yrkesidentitet (Killén, 2012). Smith (2010) framhever viktigheten av at veilederne som skal drive denne type veiledning har den rette kompetansen. Veiledning er å betrakte som en profesjon i profesjonen (Smith, 2010). Det er dermed ikke tilstrekkelig at erfarne barnevernsarbeidere får ansvaret for å veilede de nyutdannede, de som skal veilede må også ha formell veilederkompetanse for at dette skal bli vellykket. Denne typen veiledning er å finne i veiledningsteorien under det som kalles handlings- og refleksjonstradisjonen. Hovedessensen i denne tradisjonen er å trene den som veiledes til å kunne betrakte, analysere, sammenstille påstander og resonnementer, for så å kritisk analysere egen praksis (Tveiten 2008). Handlings- og refleksjonsmodellen ble lansert av Lauvås og Handal for å bidra til at yrkesutøvere fikk utvikle sine egne ideer og utvikle seg profesjonelt og faglig uavhengig av sin veileder (Skagen, 2011). Man ønsket å utvikle en veiledningsform som ikke la opp til tilpasningsdyktige nyansatte som kopierte sine veiledere. I handlings- og refleksjonsmodellen etterstrebes veiledning til å reflektere over egen praksis, for deretter å bevisstgjøre og utvikle egen kompetanse og profesjonalitet (Lauvås og Handal, 2000). 
Faglig veiledning har potensiale til å forebygge at ansatte i barnevernet blir utbrent (Killén, 1998). Veiledning av høy kvalitet har i flere utenlandske studier blitt dokumentert å ha effekt på frafall blant barnevernansatte (Collins-Camargo, 2003; Landsman, 2001; Westbrook, 2006). Videre har en effektstudie vist at spesifikk trening i samtaleferdigheter får betydning for utførelsen av barnevernfaglig arbeid (Havnen, 2002). I Norge er det imidlertid slik at den empiriske forskningskunnskapen om kollegaveiledning av nyansatte innenfor en profesjon hovedsakelig kommer fra lærerutdanningene og de pedagogiske fagmiljøene, eller fra psykologien. Innenfor barnevernsfeltet i Norge har vi lite forskningsbasert kunnskap om veiledning av nyansatte, samt eventuelle effekter av veiledning i forhold til målsetningene som er knyttet til iverksettelse av systematisk veiledning i barneverntjenesten (altså profesjonell utvikling og redusert frafall). Vi vet dermed lite om hvordan barneverntjenestene i Norge ser ut med hensyn til systematisk veiledning; hvem får veiledning, hvem gir veiledning, hvilken kompetanse har de som veileder, og hva slags form for veiledning er tilgjengelig. Videre vet vi lite om hva slags formell kompetanse barnevernet har med tanke på opplærings- og utviklingsprogrammer med veiledning som utgangspunkt.

Formålet med dette prosjektet var å undersøke hvor langt man har kommet med å innføre veiledning for nyansatte og øvrige ansatte i det kommunale barnevernet. Videre var formålet å undersøke hvilken karakter veiledningen som finnes i tjenestene har, hvor ofte og hva slags type veiledning som finns. I tillegg ønsket vi å undersøke i hvilken grad barnevernansatte oppga at de vurderer å slutte i jobben, samt om veiledning hadde innflytelse på intensjoner om å slutte i jobben. Den siste problemstillingen vi ønsket å utforske var hvilke faktorer som hadde betydning for om ansatte fikk eller ga veiledning. 


\section{Metode (avsnittstittel)}

\section{Deltakere (undertittel)}

Deltakerne besto av ansatte i det kommunale barnevernet $(N=228)$. Majoriteten av deltakerne var kvinner (86 \%), og 95.6 \% oppga at de jobbet i heltidsstillinger. I tillegg hadde 71.7 \% av respondentene lederansvar. I og med at vi ønsket å ta rede på i hvilken grad de kommunale barneverntjenestene i hele Norge tilbyr veiledning til sine ansatte, samt hvilken karakter og hvilket omfang veiledningen har, gikk henvendelsen ut til hver enkelt tjeneste. Vi ønsket å få inn svar fra minimum en person ved hver tjeneste. I utgangspunktet var ikke undersøkelsen spesielt rettet mot lederne, men henvendte seg generelt til tjenesten. Det fremkommer ikke av data hvilken posisjon eller ansvar de har som har svart på undersøkelsen men som ikke har lederansvar.

De aller fleste oppga at de jobbet utover 37.5 timer per uke. Arbeidsuker på 40-45 timer var vanligst i dette utvalget, men noen oppga også at de arbeidet mellom 50-70 timer per uke.

- $\quad$ Sett inn tabell 1 her

\section{Rekruttering og prosedyre (undertittel)}

Epostliste til alle barneverntjenestene i Norge ble skaffet av Regionalt kunnskapssenter for barn og unge (RKBU Nord), og det var 317 barneverntjenester på lista. Hver tjeneste fikk en e-post der de ble invitert til å fylle ut et elektronisk spørreskjema (Quest-Back). Det ble sendt ut purring ved to ulike anledninger. Vi fikk inn 228 svar, som utgjorde en svarprosent på 72 \%. Svarene ble anonymisert.

\section{Dataanalyse (undertittel)}


Rådata fra Quest-Back ble importert til det statistiske databehandlingsprogrammet SPSS, som ble brukt i alle analysene. Deskriptiv statistikk ble brukt til å beskrive utvalget, samt beskrive karakteristika ved veiledning i barnevernet. For å se på sammenheng mellom lederansvar og veiledning ble det gjennomført enveis ANOVA, og logistisk regresjon ble brukt til å studere sammenhengen mellom veiledning og sentrale faktorer.

\section{Måleredskaper i spørreundersøkelsen (undertittel)}

Demografiske og arbeidsrelaterte karakteristika. Personlige demografiske variabler inkluderte: alder, kjønn, arbeidssituasjon (heltid, deltid sykmeldt, permisjon), erfaring, lederansvar og antall arbeidstimer per uke.

Rutiner for veiledning i tjenestene. Følgende tema ble inkludert i spørreskjemaet: Får du veiledning og i så fall hvor ofte og lenge, gir du veiledning og i så fall hvor ofte og lenge, gis veiledning for nyansatte og i så fall hvor ofte og lenge,

Karakteristika ved veiledningspraksisen i tjenestene. Følgende spørsmål var stilt: Er veiledningen ekstern, intern, i grupper, individuell, har veileder utdanning i veiledning, er veiledningen hovedsakelig saksveiledning, debriefing eller profesjonell utvikling.

Behov i forhold til veiledning. For å ta rede på hvilke behov tjenestene hadde med tanke på veiledning, stilte vi følgende spørsmål: Vi har behov for mer opplæring i veiledning, vi har behov for ytterligere ressurser dersom veiledning for nyansatte skal kunne tilbys systematisk.

Intensjon om å slutte i jobben. For å måle ansattes intensjoner om å slutte i jobben ble det brukt en oversatt og tilpasset versjon av Arnold og Feldmans (1982) 
instrument, som er et velutprøvd instrument for å måle intensjon om å slutte i jobben. Fem spørsmål var inkludert, som ble besvart på en fempunkts Likert-skala fra “Svært enig” (5) til “ Svært uenig” (1). Spørsmålene dreide seg om framtidsutsikter i jobben, tanker om å slutte i nåværende jobb og intensjoner om aktivt å lete etter ny jobb. Reliabilitetsanalyse ga en Cronbachs alpha på 0.93.

\section{Etiske vurderinger (undertittel)}

Prosjektet er godkjent av personvernombudet for forskning (NSD). Informantene fikk informasjonsskriv på e-post med opplysning at de samtykket til å delta ved å klikke på linken til undersøkelsen. De ble også informert om anonymisering og frivillig deltakelse, samt gitt anledning til å kontakte prosjektleder dersom de ønsket mer informasjon.

\section{Resultater (avsnittstittel)}

Det første vi ville undersøke var hvor langt man har kommet med å innføre kollegabasert veiledning for nyansatte og øvrige ansatte i det kommunale barnevernet. På spørsmål om alle ansatte i tjenesten får veiledning svarte 74.1 \% ja. Samtidig svarte $65.2 \%$ at det ble gitt veiledning til nyansatte i tjenesten. Veiledningens hensikt var primært saksveiledning og debrief i konkrete saker, men mange oppga også at formålet var å gi en arena for profesjonell utvikling av de ansatte. Videre var det vanligst at veiledningen ble gitt internt, men samtidig oppga $65.7 \%$ av respondentene at de benyttet seg av eksterne veiledere. Både gruppeveiledning og individuell veiledning var vanlig i tjenestene. For detaljert oversikt over veiledning i barneverntjenestene se tabell 2.

- $\quad$ Sett inn tabell 2 og 3 her. 
På spørsmål om de mottok veiledning selv svarte imidlertid 54.9\% nei. For å undersøke om dette hang sammen med lederansvar kjørte vi en enveis ANOVA analyse. En enveis ANOVA er en analyse der man bruker statistiske metoder for å sjekke om flere grupper har samme resultat gjennom å undersøke variasjoner i middelverdiene og ved å studere om det er en eller flere faktorer som spiller inn.

Resultatene viste at de med lederansvar mottok veiledning selv i signifikant lavere grad enn de uten lederansvar ( $\mathrm{p}=.020)$. På spørsmål om de ga veiledning selv svarte 61.1\% ja. Det var en signifikant sammenheng mellom det å ha lederansvar og det å gi veiledning selv til sine ansatte $(\mathrm{p}=.000)$. Vi spurte også om de hadde utdanning i veiledning. Resultatene her viste at om lag halvparten hadde en form for veilederutdanning (53.3\%), men det var stor variasjon i hvilken veilederutdanning de hadde, fra veiledningspedagogiske utdanninger til kurs av ulike slag.

Når det gjaldt veiledningsbehovene i tjenestene svarte hele $63.8 \%$ at de hadde behov for mer opplæring i veiledning. Videre svarte $64.5 \%$ at de hadde behov for ytterligere ressurser dersom de skal klare å tilby systematisk veiledning av ansatte og nyansatte.

På bakgrunn av at andre studier har funnet at barnevernansatte i stor grad oppgir at de vurderer å slutte i jobben ønsket vi å finne ut om dette også var tilfellet i norske barneverntjenester. Vi ønsket også å studere om veiledning hang sammen med intensjoner om å slutte i jobben. Våre resultater viste at $1 \frac{1}{4}$ av de ansatte i barneverntjenestene oppga at de var enig i eller svært enig i påstanden: Jeg tenker ofte på å slutte i min nåværende jobb. 13.8\% oppga at de kan komme til å slutte i sin nåværende jobb i løpet av året, og $16.7 \%$ sa at de sannsynligvis vil lete etter ny jobb i løpet av det 
neste året. Nesten 40 \% av de ansatte oppga at de trolig vil lete aktivt etter ny jobb i løpet av de nærmeste tre årene. Vi undersøkte om det var en sammenheng mellom intensjon om å slutte i jobben og om de mottok veiledning, men fant ikke en statistisk sammenheng her. For detaljert oversikt over intensjoner om å slutte i jobben, se tabell 3.

\section{- Sett inn tabell 4 omtrent her}

Vi gjorde logistisk regresjonsanalyse for å undersøke hvilke faktorer som hadde betydning for om ansatte fikk eller ga veiledning. Regresjonsanalyse brukes for å studere sammenhengen mellom en avhengig variabel og flere uavhengige variabler, og gjør det mulig å si noe om hvordan en variabel samsvarer med en annen. Logistisk regresjon er den mest brukte regresjonsanalysen nå den avhengige variabelen er todelt (eksempelvis får veiledning/får ikke veiledning), og metoden gjør det mulig å teste sannsynligheten for at gitte faktorer har betydning for en bestemt gruppe.

De som oppga at de fikk veiledning oppga også at de hadde behov for mer opplæring i veiledning innen egen tjeneste. Vi fant en signifikant sammenheng mellom oppgitt behov for mer opplæring hos de som sa at de ga veiledning til andre. I tillegg oppga de som ga veiledning at det var behov for ytterligere ressurser dersom de skulle kunne tilby systematisk veiledning for alle nyansatte. Se tabell 5 og 6 for oversikt over faktorer som har betydning for om veiledning mottas og gis.

- $\quad$ Sett inn tabell 5 og 6 her

\section{Diskusjon (avsnittstittel)}

I følge resultatene av denne studien er det etablert veiledning til en viss grad i den kommunale barneverntjenesten i Norge. Veiledningen som er tilgjengelig er av varierende 
karakter. Det kan se ut som om det er vanligere at man har saksveiledning i konkrete saker enn veiledning med målsetting om å utvikle ansatte profesjonelt. Det kan imidlertid se ut til at det er et stykke fram til alle nyansatte har tilgang til systematisk faglig veiledning, slik myndighetene har skissert at de ønsker det. Dette henger sammen med ressurstilfang og tilgjengelig kompetanse. Dersom tjenestene skal bli i stand til å tilby systematisk veiledning til alle nyansatte, er det et uttalt behov for mer opplæring i veiledning. Det er opprettet veilederutdanninger i hele Norge (ved 6 ulike studiesteder), med siktemål om å utdanne veiledere som skal ivareta denne typen veiledning i tjenestene. Det er imidlertid ikke gitt ekstra ressurser til tjenestene slik at de kan gi personell mulighet til å ta fri for å ta denne utdanningen. For mange tjenester er det urealistisk å klare og gi fri til sine ansatte uten noen form for kompensasjon. Dette gjenspeiles i antall søkere til veilederutdanningene i Norge, samtlige studiesteder opplyser at de sliter med å rekruttere barnevernansatte til veilederutdanningene. Det er også en del studenter som har gitt opp underveis, da de ikke fikk fri likevel til å kunne ta utdanningen. Det er videre frivillig for tjenestene om de ønsker å utdanne interne veiledere. Kanskje burde det komme ei klart uttalt forventning fra myndighetene, eventuelt et pålegg, dersom man ønsker at dette skal være et prioritert kompetansehevingstiltak. I stedet for å prioritere kvalifisering av interne veiledere, ser vi at tjenestene kjøper inn ekstern kompetanse i form av ekstern veiledning. Det er mulig at det er underkommunisert at ei satsning på intern veilederkompetanse på sikt kan utgjøre lavere kostnader for tjenestene, hvis man tenker i lengre perspektiv enn det året det tar for intern personell å ta veilederutdanning.

Ressurstilfang er også ei sterkt uttalt utfordring, ifølge deltakerne i denne studien. Et stort flertall oppgir at det er umulig for tjenestene å etablere et systematisk veiledningstilbud 
uten at det gis flere ressurser. Vi vet at norske barneverntjenester allerede er presset på tid og oppgaver, og en ekstra oppgave som skal konkurrere med en allerede full timeplan er sjanseløs dersom det ikke er nok personalressurser til å ta unna arbeidsoppgavene. I denne studien var det mange som oppga at de jobbet mye overtid per uke. Det er urealistisk å forvente at disse skal rydde tid til systematisk veiledning av nyansatte uten at det gjøres noe med arbeidsmengden.

Videre var det et funn at det i stor grad var lederne i tjenestene som ga veiledning der man hadde et veiledningstilbud internt. De samme lederne oppga at de i lavere grad mottok veiledning selv. Det var stor variasjon i formell kompetanse i veiledning, og det kan derfor stilles spørsmålstegn ved kvaliteten på den faglige veiledningen som finnes i tjenestene. Faglig veiledning av høy kvalitet krever veiledere som har riktig utdannelse i dette og som har fått ferdighetstrening og veiledningspedagogisk kompetanse som er relevant for barnevernet. Mange ledere mangler formell veilederkompetanse, selv om de har lang erfaring fra tjenesten. Det er også viktig å stille spørsmålstegn ved om lederrollen er forenelig med veilederrollen. Det er mulig å tenke seg at en leder vil kunne komme i konflikt med målsettinger knyttet til profesjonell utvikling av den nyansatte og lederoppgaver knyttet til overholdelse av budsjett eller frister. Vi kjenner imidlertid ikke til forskning på dette, og kan dermed ikke belegge en slik antakelse.

Et annet viktig funn i studien var at svært mange i den kommunale barneverntjenesten ofte vurderte å slutte i jobben sin. At om lag en fjerdedel av de ansatte oppga at de ofte vurderte å slutte i jobben er et alvorlig signal om at jobben er belastende. Svært mange oppga at de aktivt vil søke etter en annen jobb. Dette funnet er sammenfallende med tidligere studier av frafall og belastninger i barnevernet (Westbrook, 2006; Ellett 2003) og er et funn 
som bør undersøkes nærmere. Hvilke belastninger i tjenestene er det som forårsaker dette ønsket om å finne seg noe annet å gjøre og hvordan kan man redusere disse belastningene slik at tjenestene ikke tømmes for kompetanse? Fremtidige studier av kommunale barneverntjenester i Norge bør undersøke dette. Vi vet fremdeles lite om hvorvidt faglig veiledning av nyansatte vil kunne ha en effekt på frafall. Det ser dessuten ut som om det veiledningstilbudet som finnes i tjenestene i dag ikke har noen effekt på ansattes ønsker om å slutte. Dette kan indikere at veiledning ikke har det store potensialet til å forbedre tjenestene som man har antatt.

Satsningen på faglig veiledning for nytilsatte i barneverntjenesten springer ut av forskning på de store belastningene knyttet til å arbeide i barnevernet (Ellett, 2003; Ede, 2011; Westbrook, 2006). Ny kunnskap om frafall i barneverntjenestene (Johansen, 2014), samt tiltak for å redusere frafall i barneverntjenestene (Befring m.fl., 2009), har ført til at man har sett til veiledningsteori. En stor utfordring er imidlertid knyttet til at det legges ulike forståelser til begrepet veiledning (Skagen, 2011), noe som gjør det vanskelig å snakke om veiledning som løsning på de utfordringene som ligger til grunn for satsningen. Barneverntjenestene i Norge har for eksempel tradisjon for å hyre inn eksterne kursholdere, som kommer og har dagskurs i en gitt tematikk, eksempelvis tilknytning. Mange ansatte i barnevernet refererer til slike dagskurs som veiledning. Intensjonen bak innføring av veiledning for nyansatte var derimot en annen: man ønsket å gi rom for profesjonell utvikling gjennom faglig veiledning av veiledningsutdannede barnevernansatte. Det er dermed i praksis et sprik mellom realiteter og politiske visjoner. Det kan synes som om at det lederne i barneverntjenestene som har svart på undersøkelsen forstår med veiledning (opplæring i spesifikke oppgaver eller debrief i vanskelige situasjoner) ikke tilsvarer en typen veiledning 
man ønsket å innføre for å legge til rette for profesjonell kompetanseutvikling i tjenestene. Dermed kan man ikke forvente at veiledningen som eksisterer i barneverntjenestene i dag har potensialet til å forebygge frafall og bygge kompetanse slik intensjonen i barnevernløftet var. Opprinnelig var det foreslått å innføre et turnusår for nyansatte i barneverntjenesten etter modell fra legestudiet, og kanskje hadde denne betegnelsen på det man ønsker å innføre gjort det lettere å være omforent hva som skal forstås med satsningen? Et annet mulig alternativ til veiledningsbegrepet er å bruke betegnelsen mentor, og det er mulig at det favner bedre det som var intensjonen med veiledet førsteår.

En annen forklaring kan være at man har iverksatt en satsning på veiledet førsteår i barneverntjenestene uten å ta inn over seg at en slik satsning også krever en god implementeringsstrategi. Dersom man ønsker at satsningen på veiledning skal materialisere seg i tjenestene må man jobbe systematisk med å implementere ny praksis, og det krever en helhetlig og gjennomtenkt implementeringsstrategi. Implementering defineres som målrettet arbeid for å iverksette planer, beslutninger eller tiltak i en kommune, organisasjon eller i generell praksis (Fixsen, Naoom, Blase, Friedman, Wallace, 2005). Å endre praksis er imidlertid utfordrende (Maybery \& Reupert, 2009). Dette gjelder også endringer i barneverntjenestenes praksis omkring nytilsatte. For å lykkes med å implementere ny praksis er det en rekke faktorer det må tas høyde for (se for eksempel Fixsen m.fl., 2005). I tillegg er det svært sentralt at implementeringsprosesser er målrettede, styrt og beskrevet i stor nok detalj til at uavhengige observatører kan observere prosessen og evaluere denne. I arbeidet med å innføre veiledet førsteår for nyansatte i barneverntjenestene har det ikke vært utviklet målrettede planer for implementering utover opprettelsen av veilederutdanninger. Videre mangler en detaljert beskrivelse av hvordan arbeidet med å iverksette ny praksis skulle 
organiseres. Det er dermed urealistisk å forvente at praksis skal endre seg kun ved at man har opprettet en utdanning for veiledere. En implementeringsstrategi der man tar høyde for å endre prosedyrer og systemer i tjenestene for å gjøre praksisendring mulig, ville kunne hatt større sannsynlighet for å lykkes (Lauritzen, Reedtz, Van Doesum, \& Martinussen, 2014). I tillegg ville en god implementeringsstrategi innebære en tilrettelegging i praksis der de som forventes å endre praksis får opplæring, ferdighetstrening, oppfølging, samt tid og rom til å drive med veiledning (Lauritzen m.fl., 2014).

Det er videre mulig at forklaringen på hvorfor man ikke ser noen effekt av veiledning på ansattes ønske om å slutte simpelthen er et uttrykk for at den veiledninga som gis ikke er god nok og at man må satse mer inngående på veilederkompetanse for å kunne se at veiledning utgjør en forskjell. Gjennom ei større satsning på veilederkompetanse, ville en kunne legge til rette for en utviklings- og læreprosess hos nyutdannede i større grad (Killen, 2012). Veiledning av høy kvalitet kan bidra til at nyutdannede lærer metodisk arbeid, utvikler fagligetiske prinsipper og yrkesidentitet (Killén, 2012), og det er dermed sannsynlig at veiledning kunne fått betydning for tjenestenes evne til å beholde talentfulle, nyutdannede etter praksissjokket.

Det var et tydelig funn i denne studien at de som ga intern veiledning også oppga at de hadde behov for mer opplæring. Som nevnt innledningsvis er veiledning å betrakte som en profesjon i profesjonen (Smith, 2010), og det er ikke tilstrekkelig at erfarne barnevernsarbeidere får ansvaret for å veilede de nyutdannede. Erfaring er viktig, men ikke nok i seg selv. I tillegg må man sørge for at tjenestene har, eller kan innhente, veiledere som har rett kompetanse (Smith, 2010). Det finnes likevel ingen studier i Norge som dokumenterer om spesialisert veilederkompetanse for barnevernansatte kan ha potensiale til å 
redusere belastninger og høye gjennomtrekkrater i tjenestene. Videre undersøkelser bør derfor gjennomføres for å kartlegge om veiledning har potensialet til å svare på målsettingene som medfølger satsningen.

\section{Konklusjon (avsnittstittel)}

Den veiledningen som finnes i barneverntjenesten i dag er i stor grad knyttet til opplæring av spesielle oppgaver og debrief i vanskelige saker. Intensjonen bar innføring av veiledet førsteår for nyansatte var imidlertid å legge til rette for profesjonell utvikling og å redusere frafall som følge av belastninger arbeidet medfører. Dersom barneverntjenesten i Norge skal kunne tilby systematisk og faglig veiledning til alle nyansatte, slik intensjonen bak satsningen var, må det gis sterkere føringer på at den formelle kompetansen til å drive profesjonell utvikling skal være et prioritert område. Det er også nødvendig med et større tilfang av ressurser i tjenestene dersom denne satsningen skal være gjennomførbar. Utdanning av interne, faglige veiledere kan være ressurstappende for tjenestene i begynnelsen, men sett i sammenheng med bruk av innkjøpt ekstern veiledning bør det være mulig å spare ressurser på sikt. Svært mange oppgir at de ønsker å slutte i sin nåværende jobb i barnevernet, og dette er et funn som må tas på alvor. Dersom veiledning skal kunne ha et potensiale i å redusere belastninger i personalgruppene, så må satsningen innføres helhjertet og ikke usystematisk og uten en implementeringsstrategi slik tilfellet ser ut til å være i dag. Videre studier bør gjøres for å ta rede på om bruk av veiledet førsteår i kommunale barneverntjenester er hensiktsmessig både med hensyn til kompetanseheving og forebygging av frafall.

\section{Begrensninger ved studien (undertittel)}


En viktig begrensning ved studien er at over $70 \%$ av respondentene er ledere. Konsekvensen av dette er at vi i stor grad mangler informasjon fra de nyansatte. Dette kan innebære at behovet for veiledning i hovedsak er vurdert ut fra et ledersynspunkt, ikke ut i fra de behovene en nyutdannet kan tenkes ha som nyansatt i tjenesten. I tillegg kan det at så mange ledere har svart på undersøkelsen bety at andre hensyn vektlegges mer i svarene enn profesjonell utvikling av nyansatte, eksempelvis tjenestens behov for mer saksrettet veiledning eller debrief. Det er mulig å tenke seg at en leder vurderer at behovet for veiledning er av en annen karakter enn det som var myndighetenes intensjon med å iverksette satsningen.

For å gi funnene om intensjoner om å slutte i jobben større perspektiv, hadde det videre vært bra å spurt de samme spørsmålene til andre yrkesgrupper. Er det bare i barnevernet at om lag en fjerdedel av arbeidsstokken vurderer å slutte i sin nåværende jobb?

\section{Referanser}

Arnold, H.J., \& Feldman, D.C. (1982). A multivariate analysis of the determinants of job turnover. Journal of Applied Psychology, 67 (3), 350-360. Doi:

dx.doi.org/10.1037/0021-9010.67.3.350

Barne- likestillings og inkluderingsdepartementet, (2011-2012). Prop. 1 S. http://www.statsbudsjettet.no/Statsbudsjettet-2012/Dokumenter/ Barne- likestillings og inkluderingsdepartementet (2012-2013). Endringer i barnevernloven. Oslo: BLD. 
Befring, E., Berg-Nielsen, T., Ekeland T.J., Haugli, T., Jacobsen, I., Jensen, O., Oterholm, I., Thomsen, E. (2009). Kompetanseutvikling i barnevernet. Kvalifisering til arbeid i barnevernet gjennom praksisncer og forskningsbasert utdanning. NOU 2008:9.

Collins-Camargo, C. G. (2003). Adventures in partnership: Using learning laboratories to enhance frontline supervision in child welfare. Professional development: The international Journal of Continuing Social Work Education, 17-31.

Ede, L. (2011). Working part time for the sake of health. I H. Nordby, Social aspects of illness, disease, and sickness absence. Oslo: Oslo Academic Press.

Ellett, A. E. (2003). A study of personal and organizational factors contributing to employee retention and turnover in child welfare in Georgia. Athens, GA: University of Georgia, school of social work.

Fixsen, D. L., Naoom, S. F., Blasé, K. A., Friedman, R. M., \& Wallace, F. (2005). Implementation research: A synthesis of the Literature. Tampa: University of South Florida.

Havnen, K. J. (2002). Målinger av samtaleferdigheter i sosialt arbeid. Nordisk sosialt arbeid, 140-146.

Johansen, I. (2014). Turnover i det kommunale barnevernet. Rapport 2014/18. Statistisk sentralbyrå.

Killén, K. (2012). Profesjonell utvikling og faglig veiledning. Et fellesfaglig perspektiv. Gyldendal Akademisk.

Killén, K. (1998). Veiledning og veiledningsmodeller i barnevernets førstelinjetjeneste. Oslo: NOVA. 
Landsman, M. (2001). Commitment in public child welfare. Social Services Review, 386419.Lauritzen, C., Reedtz, C., Van Doesum, K. T. M., \& Martinussen, M. (2014). Implementing new routines in adult mental health care to identify and support children of mentally ill parents.

Lauvås, P. \& Handal, G. (2000): Veiledning og praktisk yrkesteori. Oslo: Cappelen Akademisk forlag.

Malt, U. (2009). Debriefing. Store ledisinske leksikon. Tilgengelig på: https://sml.snl.no/debriefing

Maybery, D., Reupert, A,. (2006). Workforce capacity to respond to children whose parents have a mental illness. Australian \& New Zealand Journal of Psychiatry, 40, 657-664.

Skagen, K. (red) (2011). Kunnskap og handling i pedagogisk veiledning. Bergen: Fagbokforlaget.

Smith, K., \& Ulvik, M. (red) (2010). Veiledning av nye lærere. Nasjonale og internasjonale perspektiver. Oslo: Universitetsforlaget.

Tveiten, S. (2008): Veiledning mer enn ord. Bergen: Fagbokforlaget.

Westbrook, T. E. (2006). Improving retention among public child welfare workers. Administration in social work, 37-62. 
Tabell 1

Deskriptiv Statistikk for Demografiske Variabler $(N=228)$

Kjønn Kvinner $\quad 86 \%$

Menn $\quad 14 \%$

Alder

$\begin{array}{ll}<30 \text { år } & 5.3 \% \\ 31-40 \text { år } & 20.6 \% \\ 41-50 \text { år } & 35.5 \% \\ 51-60 \text { år } & 27.2 \% \\ >60 \text { år } & 11.4 \%\end{array}$

Arbeider

heltid

Ja

$95.6 \%$

Nei

$4.4 \%$

Lederansvar

\begin{tabular}{ll} 
Ja & $71.7 \%$ \\
Nei & $28.3 \%$ \\
\hline
\end{tabular}


Tabell 2

Veiledning i barneverntjenestene $(\mathrm{N}=228)$

Alle ansatte får veiledning

Ja

Nei

$74.1 \%$

$25.9 \%$

Veiledning til nyansatte:

Ja

$65.2 \%$

Nei

$34.8 \%$

Veiledningen gis:
Av internt personell Av eksternt personell Individuelt

I grupper
$98.5 \%$

$65.7 \%$

$95.7 \%$

$88.1 \%$ 
Tabell 3

Veiledningens karakter

Veiledningen i min tjeneste

er primært saksveiledning $(N=137)$

Ja $\quad 97.1 \%$

Nei $\quad 2.9 \%$

Veiledningen i min tjeneste

er primært profesjonell utvikling $(N=107)$

Ja $\quad 84.1 \%$

Nei $\quad 15.9 \%$

Veiledningen i min tjeneste

er primært debriefing $(N=112)$

Ja $\quad 92.9 \%$

Nei $7.1 \%$ 
Tabell 4

Intensjoner om å slutte i jobben $(\mathrm{N}=225)$.

Jeg tenker ofte på å slutte i min nåværende jobb

svært enig/enig

22.2

verken enig eller uenig $\quad 17.3 \%$

svært uenig/uenig

60.4

Jeg kan komme til å slutte i min nåværende jobb i løpet av året

svært enig/enig

$13.8 \%$

verken enig eller uenig $\quad 15.1 \%$

svært uenig/uenig

$71.1 \%$

Jeg vil sannsynligvis lete aktivt etter ny jobb det neste året

svært enig/enig

$16.7 \%$

verken enig eller uenig

$20.8 \%$

svært uenig/uenig

$62.5 \%$

Jeg oppfatter mine framtidsutsikter i denne jobben som dårlige

svært enig/enig $13.3 \%$ verken enig eller uenig $\quad 21.8 \%$ svært uenig/uenig $64.9 \%$

Jeg vil trolig lete aktivt etter ny jobb i løpet av de nærmeste tre årene

svært enig/enig

$37.8 \%$

verken enig eller uenig

svært uenig/uenig
$26.2 \%$

$36.0 \%$ 
Tabell 5

Faktorer som har betydning for om veiledning mottas $(N=162)$

\begin{tabular}{lcccccc}
\hline Variabel & $\mathrm{B}$ & $\mathrm{S} . \mathrm{E}$ & Wald & $\mathrm{df}$ & $\mathrm{p}$ & Odds ratio \\
\hline Behov for mer opplæring & .97 & .46 & 4.42 & 1 & $.04^{*}$ & 2.63 \\
Behov for mer ressurser & -.84 & .49 & 3.02 & 1 & .08 & .43 \\
Kjønn & .77 & .53 & 2.09 & 1 & .15 & 2.15 \\
Intensjon om å slutte & .02 & .03 & .32 & 1 & .57 & 1.02 \\
\hline
\end{tabular}


Tabell 6

Faktorer som har betydning for om veiledning gis $(N=162)$

\begin{tabular}{lcccccc} 
Variabel & B & S.E & Wald & df & p & Odds ratio \\
\hline Behov for mer opplæring & .90 & .44 & 4.29 & 1 & $.04^{*}$ & 2.47 \\
Behov for mer ressurser & -1.00 & .51 & 3.83 & 1 & $.05^{*}$ & .37 \\
Kjønn & -.04 & .48 & .01 & 1 & .94 & .97 \\
Intensjon om å slutte & .04 & .03 & 1.29 & 1 & .26 & 1.04 \\
\hline
\end{tabular}

